\title{
The impact of disciplinarity on cognitive leadership frames of academic deans in Jordanian universities
}

\author{
Aieman Ahmad Al-Omari a,b,1* \\ ${ }^{a}$ The Hashemite University, Faculty of Educational Sciences, Zarqa, Jordan \\ ${ }^{\mathrm{b}}$ Sabbatical at Sultan Qaboos University, College of Education, Oman \\ 1 aieman66@hu.edu.jo \\ * corresponding author
}

ARTICLE INFO

Article history

Received 2020-04-25

Revised 2020-07-2

Accepted 2020-08-20

Keywords

Academic deans

Cognitive leadership frame

Education in Jordan

\begin{abstract}
The purpose of this study is to address how academic deans at Jordanian Universities perceive their cognitive leadership frames (bureaucratic, collegial, political, and symbolic frames) based on their disciplines. One hundred thirty-four academic deans have completed the survey and used in this study, with a response rate of $93 \%$. As for discipline, there were scientific 56 and 78 humanities disciplines. A questionnaire with 22 items grouped into four scales, one each for the bureaucratic, collegial, political, and symbolic frames. The results indicated that the bureaucratic leadership frame has a high level than all other cognitive leadership frames, followed by a political leadership frame with a high level, followed by a collegial leadership frame with a moderate level, and a symbolic leadership frame moderate level. T-test results revealed that the Bureaucratic leadership frame and political leadership frame had significant differences in favor of scientific discipline. In comparison, collegial and symbolic leadership frames had no significant differences. The study recommended that university leaders should support academic deans to enroll workshops and partake comprehensive training on cognitive leadership frames to help them realize their full potential in contributing and developing their colleges and universities.
\end{abstract}

This is an open access article under the CC-BY-SA license.

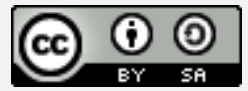

\section{Introduction}

The analysis of higher education leadership is complex due to the complex nature of the organization [1], unusual dual control structures, and the discrepancy between professional and administrative authority [2]. Current leadership theories, including trait theories, power and influence theories, and contingency theories fall short in higher education research, as they encourage a lead view of leadership as an individual endeavor [3]. Al-Omari explains study revealed that there were characteristics of academic deans; Initiating Structure :openness to different strategies in problemsolving, the use of annual review to make sure staff/ faculty members' work to capacity, and flexibility in the amount of detail they provided on how the work should be done [4]. The contrast in Initiating Structure was in how they outlined their work. Results demonstrate that the female dean was more cooperative with other faculty and staff members. When it came to Consideration, both deans (male and female) agreed upon having an open door policy with their faculty, willing to make changes in the department, and that having high morale was very important within the department. 
More, the difficulty of the professional bureaucracy in higher education and the variety in perspectives competing for the right to reality [5] in colleges and universities today generate the need for leadership that clearly embraces a multiplex of viewpoints rather than one based on the presumption of a single and common reality [1]. For these reasons, it has been found that cognitive theories, and in particular the use of cognitive "frames" first proposed by [6], are the most appropriate for studying leadership in higher education. Cognitive leadership frames are typography of organizations resulting from the fact that leaders make judgments about the dynamics of their social organizations. By modifying the cognitive frame or "lens" that is used, a leader may perceive several viewpoints on the same selection on phenomena. Cognitive leadership frames may allow a leader to filter out specific issues while allowing others to move through [6]. The frames decide how to identify challenges, what questions are being posed, what types of knowledge are being collected, and what possible solutions are being considered [7]. They are helping us to "order the universe and decide what to do"[8].

In which leaders view their organizations, four distinct organizational frameworks have been proposed: these are the bureaucratic, collegial, political, and symbolic frameworks. Academic institutions are dynamic organizations with diverse members and thus reflect a multi-reality environment. For this cause, leaders with the ability to use more than one cognitive framework would be more effective than those who evaluate and solve issues from a singular viewpoint [6]-[10]. The role of the academic dean is the one that has appeared more frequently in the higher education literature. Universities have been said to be just as strong as their schools, and schools are only as strong as their deans [28]. The role of academic deans has been studied for their ambiguity [11], their selection process [12], their evaluation process [13], [14], and their Structure [15]. In Jordanian universities, it was minimal research papers focus on academic deans as a whole. Yet, there is very little understanding of how academic disciplinary background impacts the behavior of academic deans and leadership overall. The Hashemite Kingdom of Jordan is located in the heart of the Middle East. The capital is Amman. Countries bordering Jordan are south-eastern Saudi Arabia, east Iraq, west Palestine, and north Syria. Jordan has access to the Red Sea through Aqaba port city, located at the northern end of Aqaba Gulf. Higher education in Jordan plays a key role in the process of comprehensive development.

During the last two decades, the sector of higher education in Jordan witnessed a prominent development as well as progress evidenced by the increasing number of institutions of higher education, enrolled students, faculty members, administrative and academic members, and size of expenditures in this sector. Despite the limited financial resources in the kingdom, higher education lies within the priorities of the country due to the role it plays in promoting the economic, social, and knowledge level of the Jordanian citizens. The Ministry of Higher Education and Scientific Research (MOHESR) is responsible for implementing the higher education policy, coordination among higher education institutions, conducting agreements with other countries, recognition of universities and degrees from other countries, assisting the Council of Higher Education and providing it with necessary studies. The Ministry also works on bridging the gap between higher education output and the labor market to respond to the present and future needs of qualified and specialized cadres in various areas of knowledge. The Jordanian higher education in numbers (2018-2019): 10 Public universities, 19 private universities, 44 Community colleges, 282,403 Students (54\% Females), 42,000 international students from 105 countries, 10,812 Teaching staff, and 1,168 Study programs [36].

While the administrative responsibilities of deans are relatively consistent from unit to unit, the background and training of Deans tend to vary greatly by discipline. Most deans rise to their positions through the faculty ranks, and this means that each has been socialized in a specific discipline with its own related set of values, norms, and methods for viewing the world [29]-[31]. In Jordanian universities, a survey of the relevant literature indicated a paucity of research papers focus on academic deans as a whole. Yet, there is very little understanding of how academic disciplinary background impacts the behavior of academic deans, and leadership overall. The study surveys deans from a range of disciplines and examines whether and how deans from different backgrounds approach their administrative leadership differently. 
This research study investigates the apparent effects of disciplinarity on cognitive leadership frames in the higher education setting. Thus, this study is guided by the following research question:

Question 1: How do academic deans at Jordanian Universities' perceive their cognitive leadership frames (bureaucratic, collegial, political, and symbolic frames)?

Question 2: Do academic dean's cognitive leadership frames (bureaucratic, collegial, political, and symbolic frames) at Jordanian Universities differ based on their disciplinary field?

The work and performance of academic deans have been observed to be crucial to the success of individual units [32]. Yet the approaches to administrative work can vary greatly depending on the orientation of the individual leaders, and his or her use of dimensional perspectives or cognitive "lenses" and their combinations when making decisions and interacting with people. It could significantly inform higher education management in several ways: It could help inform better ways of identifying good future leaders. It could inform policymakers with the development of selection processes, assessment, or evaluation in the promotion and advancement of leaders to the deanship role. It could indicate the need for support or training of current and future deans. The findings of this study clarify the deans' responsibilities that most of them rise to their positions through the faculty ranks, which means that each has been socialized in a specific discipline with its own related set of values, norms and methods for viewing the world that may be supported by the literature [29]-[31].

\section{Method}

A search of the literature on disciplinarity and cognitive leadership styles uncovered only one significant research study on the effects of disciplinarity and the leadership behavior of academic deans to date. This lack of attention to one of the most important leadership roles in higher education clearly demonstrates a need for further scholarly research in this area. This study was a quantitative descriptive method conducting through utilizing cognitive leadership frames (bureaucratic, collegial, political, and symbolic frames); a set of a series of four scales, one each for the bureaucratic, collegial, political and symbolic frames that represent the potential cognitive frames as expressed through a list of leadership activities potentially performed by the deans. These items built upon work analyzing the impact of disciplinarity on academic deans' self-reported leadership behaviors [27].

The target population for the study included all academic deans in Jordanian universities during the first semester of academic year 2017/2018, a total of 200 academic deans representing a variety of academic majors. A sample of 150 academic deans was chosen randomly, but only 134 academic deans satisfactorily completed the survey response rate of $93 \%$. As for discipline, there were scientific 56 and 78 humanities disciplines. The instrumentation used for the survey part was cognitive leadership frames (bureaucratic, collegial, political, and symbolic frames). Twenty-two items grouped into four scales, one each for the bureaucratic, collegial, political, and symbolic frames. Academic deans typically perform the 22 behaviors. Following each behavior are four statements that may, or may not, relate to the academic dean's own reasons for performing the behavior. Responses are rated on a 5-point Likert scale ranging from "Strongly Disagree" (1) to "Strongly Agree" (5), with scale scores created by taking the mean of each subscale's items.

To examine the validity of the instrument (face validity evidence) was presented to post-secondary education experts. They were asked to check whether the statements in the instrument are clear and linked appropriately with the areas that were classified to them in advance. Regarding the reliability of the instrument, a split-half procedure was used; a pilot study had been conducted. Fifteen academic deans participated in the pilot study; those academic deans did not participate in the final study. Stability coefficients for the instrument in each case were $0.88,0.78,0.75$, and 0.83 for the first, second, third, and fourth subscales, respectively. These values can be considered reasonably satisfactory to support the objectives of the current study.

The Statistical Package for Social Sciences (SPSS) version 17 was used to analyze the data collected from the surveys. Descriptive statistics providing means and standard deviations were calculated for the first question. T-test was employed to answer the second question. To understand the results of this study, it was important to set specific cut points to interpret the participant's total scores related to their perception of their cognitive leadership frames (bureaucratic, collegial, political, and symbolic frames. Regarding the cut points, it should be noted that the researcher used the response 
scale of each item that ranged from 1 to 5 to determine these cut points according to the following manner: $1-2.33=$ low, from 2.34 to $3.67=$ moderate, and 3.68-5.00 = high levels.

\section{Results and Discussion}

Define the four frames or dimensions that have been found to classify behaviors best and leadership styles in higher education, see Fig 1. These include four classifying dimensions [6] that have come to be labeled in the context of higher education as Bureaucratic, Collegial, Political, and Symbolic [10].

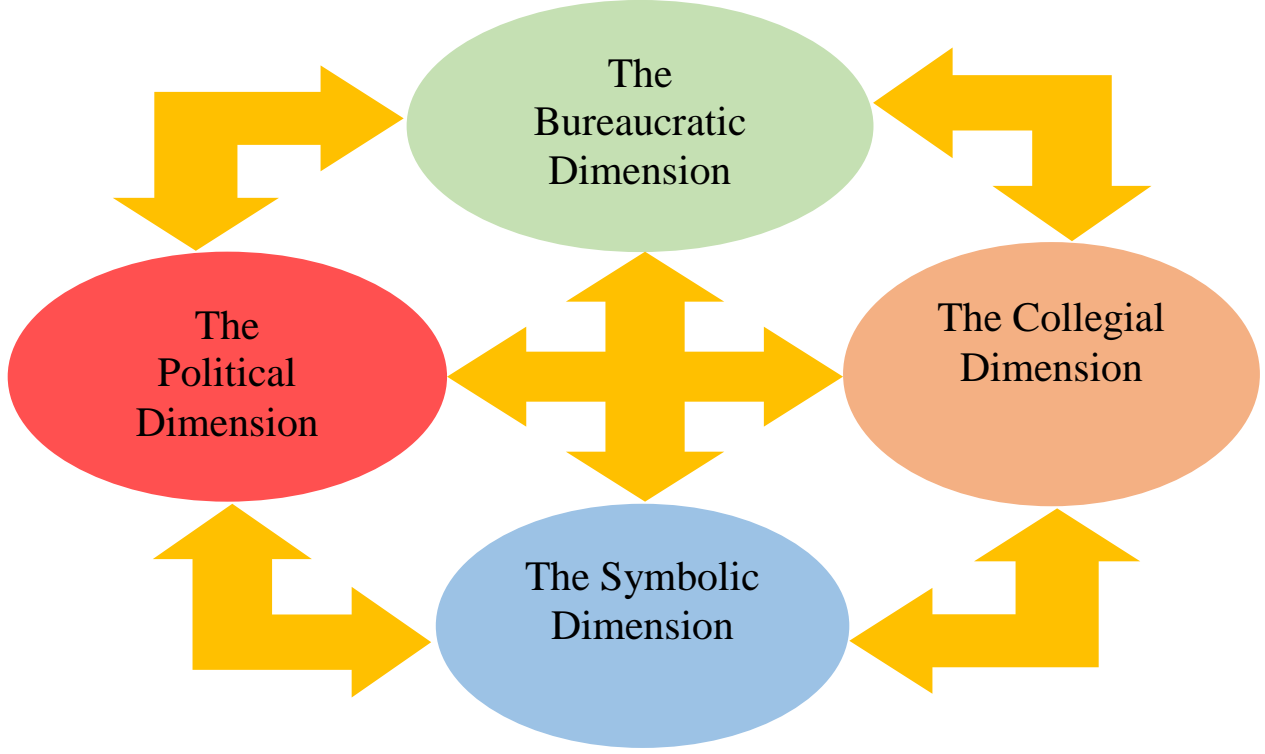

Fig. 1. The four frames (dimensions) that classify behaviors and leadership styles in higher education

\section{1) The Bureaucratic Dimension}

The bureaucratic or "structural" frame is drawn from a long tradition of organizational theory with origins in organizations' logical, standardized Structure and operations, which also seeks to illustrate "social architecture" and its implications. Classical theorists whose work forms the underpinnings of the bureaucratic model include Fayol, Mooney, and Urwick [28]. These theorists codified their insights by drawing on principles prominent in such areas as military and engineering, focusing on notions of precisely defined, hierarchically arranged jobs, with clear lines of command and communication.

The bureaucratic leadership dimension promotes the notion that organizations are increasing their productivity and enhancing their output by the proper division of labor and specialization formation. Leaders create rational rules, policies, and predictable operating procedures to govern work conditions and to define standard procedures clearly. The organization's existence determines or prescribes the one best Structure, and each organization operates to attain the set goals and objectives. With the aid of vertical and lateral integration, teamwork, and controls, individuals and teams work together to achieve these objectives. Every organization is viewed as having a core processor "technology" that includes organizational beliefs about linking inputs and outcomes.

According to this frame, leadership roles are based on ability and expertise-how [16]. Overall else, it is the analytical consistency of rational decisions taken by leaders that are valued. Leaders are searching for the right combination of power and direction so that individuals and organizations are not either too independent or too unsupported, and objectives are not over or under-defined. Similarly, leaders try to build structures for their organizations or divisions that, depending on changing conditions, would not be too loose or too rigid, and restructuring is considered one of the most significant methods leaders have to create change according to the bureaucratic frame. 
2) The Collegial Dimension

The collegial dimension, borrowed from the "human resources" viewpoint for higher education, defines the relationships between the institution's members and the institution itself. Instead of believing that individuals represent organizational needs, leadership actions, according to this aspect, assume that organizations operate to meet individual needs. Collegial-style leadership understands that a good job-to-individual fit enables the individual to find meaning and satisfaction in their work. At the same time, the organization takes advantage of the productivity, energy, creativity, and talent of the individual. When the match between individuals and organizations is perfect, both will enjoy the benefits, and both will suffer if the match is bad.

Leaders seek to establish a collegial culture in which consensus, shared power, shared responsibility, and common goals are emphasized [10]. Collegial-style leaders should try to deemphasize the differences in rank and allow participants to collaborate and engage as partners in what can be considered a "colleague community." In their study of the university faculty, [17] found that three major components of collegiality are equally important expertise in various fields, the right to engage in institutional relations, and a comfortable and compassionate scholarly company in which partnerships, good discussion, and mutual assistance will flourish [17]. Collegial leadership stresses teamwork as the hallmark of an effective organization [16].

According to the collegial dimension, leaders need to exemplify the group's values in an exemplary way; adhere to the group's expectations of what leadership should be; use the existing channels of communication; never issue orders that will not be obeyed; listen carefully to group expectations; minimize status gaps to preserve open communication, and encourage the group's selfcontrol or self-discipline [10]. Collegial leaders balance the need for task fulfillment with the development of relationships, encourage a "shared language" among members, and above all, recognize the needs of the members of the community as the key to effectiveness and progress.

\section{3) The Political Dimension}

Organizations are political action systems similar to the type of political leadership, consisting of coalitions with various aims and priorities. Enduring differences between members of the coalition, such as views of reality, values, beliefs, or interests, is bound to generate conflict, as is the allocation of limited resources [16]. The style of political leadership assumes that relations of power, scarcity, interdependence, and divergent interests often yield political action [9], [18].

The political perspective asserts that organizations are both "arenas" where internal politics are negotiated, and also political "agents" existing within wider arenas or political "ecosystems" [19]. As arenas, they provide a setting where a widely varied array of divergent interests and agendas are in an ongoing state of interplay. As agents or actors, organizations "exist, compete, and co-evolve" [9] in ecosystems with clusters of other organizations, each seeking to fulfill its own agenda. Relationships between and within ecosystems can be both collaborative and competitive.

According to the political frame, positions of leadership are determined by the control of key resources [16]. Politics are at the heart of decision-making for leaders, and successful ones are able to influence and shape the rules of the game. Leaders as politicians are described by [9] to have four key skills: agenda setting [20], [21], mapping the political terrain [22], [23], networking, and forming coalitions [20], [22], and bargaining and negotiating [24]. Social control is considered to be vital for a leader since upholding one's authority depends on the degree to which partisans remain fearful or respectful of that authority. In short, the political frame asserts that those leaders who obtain and use power best will be the most successful.

\section{4) The Symbolic Dimension}

The symbolic style of leadership is based on understanding symbolic context and belief. Symbolically driven leadership assumes that organizations have several levels of meaning. Organizations are guided by their clearly different values and culture, and there will be deeper and deeper levels to be investigated for those researchers willing to clear away the consecutive layers.

To a symbolically oriented leader, the ceremonies and practices, traditions, and stories, symbols, and legends of an organization all provide clues to the particular set of core assumptions embedded in an organization. Some of these are being performed internally in the organization's "theatre." In fact, the symbolic viewpoint describes an organization as "the awareness of a common reality" [25]. 
Symbolically-oriented leaders emphasize expressive rather than instrumental actions [26]. They know that what matters about any event or process in an organization is not what happened but what it means and how the organization's members interpret it and that meanings are not "given" to us, we must create them [9]. Therefore, in the face of uncertainties, leaders need to create symbols to resolve confusion, find direction, and help the organization's members find purpose [16]. Leaders who understand the power of symbols and strive to strengthen their meaning are better equipped to understand and influence their organizations [9]. Use of metaphor, humor, and play brings out the human side of organizational work and can help unify members, and use of "visions"-visions for the future, visions of where the organization can go are powerful tools for leaders. Symbolically-oriented leaders are always aware of the symbolic consequences of their actions, and understand their roles as they affect the social construction of social "reality" construction process [25].

One recent study has utilized the dimensional perspective in regard to the behavioral leadership of academic deans. [27] sought to identify constructs associated with the four behavioral orientations (dimensions) that would distinguish academic deans from various discipline groups. She used a dimensional perspective to classify behaviors to determine whether deans were more inclined to behave in ways associated with one-dimensional orientation over another according to their academic discipline. Disciplines provide members with distinct attitudes, beliefs, norms, ways of doing things, and ways of looking at the world. Their impact on members' behavior may be deeper than was once believed. This disciplinary influence creates distinct preferences for filtering information, framing questions, problems, and solution sets, and ultimately understanding and leading academic units [27]. These preferences represent cognitive lenses or frames [10], [2]. They are cognitive tools that academic deans may rely on, especially given that there is very little comprehensive training or education in management and administrative leadership available to academic deans other than their prior training as scholars [28]. Potentially there is a direct relationship between the academic backgrounds of deans and the choice of specific cognitive frames they utilize in performing their leadership work.

Faculty member behavior differs according to the norms and expectations of the discipline. Notable differences in decision-making, goal-orientation, how faculty members' time is spent, collaborative behavior, communication styles, and even predictable differences in faculty members' values and political orientation have been found. Research One: How do academic deans at Hashemite University perceive their cognitive leadership frames (bureaucratic, collegial, political, and symbolic frames)? The research question was about determining the academic deans at Hashemite University to perceive their cognitive leadership frames (bureaucratic, collegial, political, and symbolic frames). Means and standard deviations were used to answer this question. Table 1 presents the means and standard deviations for each cognitive leadership frames. As shown in Table 1, the mean of "Bureaucratic leadership frame" with high level, mean=3.78, and $\mathrm{SD}=.36$ is higher than all other cognitive leadership frames, followed by "Political leadership frame" with high level, mean=3.73, and $\mathrm{SD}=.38$, followed by "Collegial leadership frame" with Moderate level, mean $=3.40$, and $\mathrm{SD}=.59$, and "Symbolic leadership frame" with Moderate level, mean=3.28, and SD=.54.

Table 1. Means and standard deviations for each cognitive leadership frames perceived by academic deans

\begin{tabular}{|c|c|c|c|c|}
\hline No. & Cognitive Leadership Frames & Mean & SD & Level \\
\hline 1. & Bureaucratic & 3.78 & 36 & High \\
\hline 2. & Collegial & 3.40 & 59 & Moderate \\
\hline 3. & Political & 3.73 & 38 & High \\
\hline 4. & Symbolic & 3.28 & 54 & Moderate \\
\hline
\end{tabular}

Question Two: Do academic dean's cognitive leadership frames (bureaucratic, collegial, political, and symbolic frames) at Jordanian Universities differ based on their disciplinary field?

T-test was conducted to determine whether there are significant mean differences in the academic dean's cognitive leadership frames (bureaucratic, collegial, political, and symbolic frames) at Jordanian Universities' differ based on their disciplinary field. Table 2 presents t-test results, revealed that the "Bureaucratic leadership frame" and "Political leadership frame" had significant differences in favor of "scientific field". While "Collegial" and " "Symbolic" leadership frames had no significant differences. 
Table 2. T-test, means and standard deviations for "Cognitive leadership frames" as perceived by academic deans at Hashemite University

\begin{tabular}{|c|c|c|c|c|c|c|c|}
\hline Cognitive leadership frames & discipline & $\mathbf{N}$ & Mean & SD & $\mathbf{t}$ & df & Sig. \\
\hline \multirow[t]{2}{*}{ Bureaucratic } & scientific & 56 & 3.88 & .367 & \multirow{2}{*}{2.642} & \multirow{2}{*}{132} & \multirow{2}{*}{$.009 *$} \\
\hline & humanities & 78 & 3.71 & .357 & & & \\
\hline \multirow{2}{*}{ collegial } & scientific & 56 & 3.41 & .553 & \multirow{2}{*}{.205} & \multirow{2}{*}{132} & \multirow{2}{*}{.838} \\
\hline & humanities & 78 & 3.39 & .624 & & & \\
\hline \multirow[t]{2}{*}{ political } & scientific & 56 & 3.82 & .390 & \multirow{2}{*}{2.142} & \multirow{2}{*}{132} & \multirow{2}{*}{$.034^{*}$} \\
\hline & humanities & 78 & 3.68 & .374 & & & \\
\hline \multirow[t]{2}{*}{ symbolic } & scientific & 56 & 3.31 & .523 & \multirow{2}{*}{.518} & \multirow{2}{*}{132} & \multirow{2}{*}{.605} \\
\hline & humanities & 78 & 3.26 & .559 & & & \\
\hline
\end{tabular}

5) Delimitations and limitations of the study

The study was delimited to the academic deans in Jordanian universities during the first semester of the academic year 2017/2018, who responded to the study's survey. The bureaucratic, collegial, political, and symbolic frames were used to measure how do academic deans perceive their cognitive leadership frames. It was assumed that the variable "disciplinary field" was measurable; that the participants were truthful in their survey responses, providing accurate quantitative data; and the researcher approached the study in an unbiased manner and followed standards of academic rigor for objectivity.

On the other hand, [16] observed that collegial-style leadership emphasizes teamwork as the hallmark of an effective organization, which has not happened to an efficient level among academic deans in Jordanian universities. This result may have consisted with [34] study that reveals all major decisions impacting the operations of colleges are centralized at the university level, the practice of faculty members of shared governance in all aspects (university board's role, the president's board's role, faculty members' role, Joint Decision-Making, Organizational Environment, Climate for Governance) in the Jordanian universities was in a low degree. Also, faculty members may see that the system is too autocratic, too inconsistent, unfair, and generally non-inclusive [34].

The point out that symbolically oriented leaders emphasize expressive rather than instrumental actions. They know that what matters about any event or process in an organization is not what happened. Still, what it means and how the members of the organization interpret it, and that meanings are not "given" to us, we have to develop them, which is not enough among academic deans [26], [9]. Higher education leaders "academic deans" may have passive or absent roles with their employees in their university regarding "collegial" and "symbolic" leadership frames, which is a valuable source of decision making effectiveness and in their activities and to promote understanding and goals that align with university needs. One key to increasing academic dean's abilities and desire to participate in leadership frames in their professional roles is increases institutional support. Institutions could offer optional training so that those unfamiliar with leadership frames could learn tips and best practices for effective use. In addition to that, Taylor [33] suggested that the mark of a leader and an attribute that puts him or her in a position to attract followers is when the leader demonstrates the ability to see more clearly the best destination for the organization. In educational institutions, leadership is one of the crucial steps for providing educational reforms and organizational development [35].

Based on the results of the research, and what Wolverton, Gmelch, Montez, and Nies identifies the cognitive tools the academic deans may rely on, there seems to be little thorough management and administrative leadership training or education available to academic deans other than their prior training as professors [28]. Therefore, the recommendation of this study encourages university leaders to support academic deans to enroll workshops and comprehensive training on cognitive leadership frames to help them realize their full potential in contributing and developing their colleges and universities. The research has the strength to advise policy and practice at the universities in a variety of ways. That involves the form of disciplinary background, or even the most effective gender administrators may be regarded when they make appointments to the position of dean.

\section{Conclusion}

The study results showed that the mean of the bureaucratic leadership frame with high level is higher than all other cognitive leadership frames, followed by political leadership frame, with high level, followed by collegial leadership frame with moderate level, and symbolic leadership frame with 
moderate level. T-test results revealed that bureaucratic leadership frame and political leadership frame had significant differences in favor of scientific discipline. While collegial and symbolic leadership frames had no significant differences. The results of this study indicated that the disciplinary background of academic deans is reflected in their actions. Since an academic dean's use of bureaucratic leadership frame as reported for this study appear to differ according to the dean's disciplinary field of study. The pattern of findings indicates that deans who have socialized in scientific disciplines have, among them, diverse approaches to leadership, which are bureaucratic and political leadership frames.

\section{References}

[1] M. D. Cohen, and J.G. March, Leadership and ambiguity. New York: McGraw Hill, 1974, available at: Google Scholar.

[2] E. M. Bensimon, A. Neumann, and R. Birnbaum, Making Sense of Administrative Leadership. The " $L "$ Word in Higher Education. ERIC Digest. Washington, DC: ERIC Clearinghouse on Higher Education, 1989, available at: Eric.ed.gov.

[3] A. M. Cohen, F. B. Brawer, (Eds), Managing community colleges: A handbook for effective practice. San Francisco, CA: Jossey-Bass, 1994, available at: Eric.ed.gov.

[4] A. A. Al-Omari, Perceived leadership style of Jordanian academic deans in higher education institutions: Qualitative study. Near and Middle Eastern Journal of Research in Education, 3(1), 1-8., 2010, doi: 10.5339/nmejre.2010.3.1.

[5] K. J. Gergen, The saturated self: Dilemmas of identity in contemporary life. New York, NY: Basic Books, 1991, available at: Google Scholar.

[6] L. G. Bolman, and T. E. Deal, Modern approaches to understanding and managing organizations. San Francisco, Jossey-Bass, 1984, available at: Google Scholar.

[7] D. Goleman, Vital lies, simple truths: The psychology of self-deception. New York, NY: Simon and Schuster, 1985, available at: Google Books.

[8] E. M. Bensimon, Understanding administrative work. In A.M. Cohen, F.B. Brawer \& Associates' Managing community colleges: A handbook for effective practice. San Francisco, CA: Jossey-Bass, 1994, available at: Eric.ed.gov.

[9] L. G. Bolman, and T. E. Deal, Reframing organizations: Artistry, choice, and leadership (3rd ed.) San Francisco, Jossey-Bass, 2003, available at: Google Scholar.

[10] R. Birnbaum, and others, How Colleges Work. The Cybernetics of Academic Organization and Leadership. San Francisco, CA: Jossey-Bass, 1989, doi: 10.1080/07377366.1989.10401184.

[11] M. Wolverton, M. L. Wolverton, and W. H. Gmelch, The impact of role conflict and ambiguity on academic deans. Journal of Higher Education, 70 (1), 80-106, 1999, doi: 10.1080/00221546.1999.11780755.

[12] S. B. Twombly, The process of choosing a dean. Journal of Higher Education, 63 (6), 653-683, 1992, doi: $10.1080 / 00221546.1992 .11778394$.

[13] T. J. Lasley, and M. Haberman, How do university administrators evaluate education deans? Journal of Teacher Education, 38 (5), 13-16, 1987, doi: 10.1177/002248718703800504.

[14] T. Matczynski, T. J. Lasley, and M. Haberman, The deanship: How faculty evaluates performance. Journal of Teacher Education, 40 (6), 10-14, 1989, doi: 10.1177/002248718904000603.

[15] K. M. Moore, A. N. Slaimebene, J. D. Marlier, and S. M. Bragg, The Structure of presidents' and deans' careers. Journal of Higher Education, 54, 500-515, 1983, doi: 10.1080/00221546.1983.11780171.

[16] J. B. Berger, and J. F. Milem, Organizational behavior in higher education and student outcomes. In J.C. Smart (Ed.) Higher Education: Handbook of Theory and Research, Volume XV (pp. 268-338). New York, NY: Agathon, 2000, available at: Google Scholar. 
[17] H. R. Bowen, and J. H. Schuster, American professors: A national resource imperiled. New York, NY: Oxford University Press, 1986, available at: Eric.ed.gov.

[18] J. V. Baldridge, Power and conflict in the university. New York, NY: Wiley, 1971, available at: Eric.ed.gov.

[19] J. F. Moore, Predators and prey: A new ecology of competition. Harvard Business Review, 75-86, 1993, available at: Google Scholar.

[20] J. P. Kotter, The leadership factor. New York, NY: Free Press, 1988, available at: Google Scholar.

[21] H. Smith, The power game. New York, NY: Random House, 1988, available at: Google Scholar.

[22] J. Pfeffer, Managing with power: Politics and influence in organizations. Boston: Harvard Business School Press, 1992, available at: Google Books.

[23] F. Pichault, Ressources humaineset change mentstrategique: Vers unmanagement politique [Human resources and strategic change: Toward apolitical approach to management]. Brussels, Belgium: DeBoeck, 1993, doi: hdl.handle.net/2268/76360.

[24] D. A. Lax, and J. K. Sebenius, The manager as negotiator. New York, NY: Free Press, 1986, available at: Google Scholar.

[25] G. Morgan, Images of Organization. Thousand Oaks, CA: Sage Publications, 1997, available at: Eric.ed.gov.

[26] J. Pfeffer, Power in organizations. Boston, MA: Pitman, 1981, available at: Google Scholar.

[27] M. Del Favero, The social dimension of academic discipline as a discriminator of academic dean's administrative behaviors, The Review of Higher Education, 29(1), 69-96, 2005, doi: 10.1353/rhe.2005.0066.

[28] M. Wolverton, W. H. Gmelch, J. Montez, and C. T. Nies, The changing nature of the academic deanship. ASHE-ERIC Higher Education Report, v.21, no.1, 175. Washington, DC: Jossey, 2001, eric.ed.gov.

[29] R. Kelly, and B. D. Hart, Role preferences of faculty in different age groups and academic disciplines. Sociology of Education, 44, 351-357, 1971, available at: Google Scholar.

[30] S. M. Lipset, and E. C. Ladd, The divided professorate. Change, 3(3), 54-60, 1971, doi: 10.1080/00091383.1971.10567994.

[31] J. C. Smart, K. A. Feldman, and C. A. Ethington, Academic disciplines: Holland's theory and the study of college students and faculty. Vanderbilt University Press, 2000, available at: Google Books.

[32] V. Rosser, L. K. Josrund, and R. H. Heck, Academic deans and directors: Assessing their effectiveness from individual and institutional perspectives. Journal of Higher Education, 74 (1), 1-25, 2003, doi: 10.1080/00221546.2003.11777185.

[33] T. A.Taylor, Examination of leadership practices of principals identified as servant leaders. Dissertation Abstracts International, 63 (05), 1661, 2002. (UMI No. 3052221), doi: 10.1080/13603120701408262.

[34] K. Bani-Hani, A. Al-Omari, The shared governance practices in the Jordanian Universities: Faculty members' perspective. Journal of Institutional Research South East Asia (JIRSEA), 12(2), 152-179, 2014, available at: Google Scholar.

[35] K. Leithwood, K. S. Louis, S. Anderson, \& K. Wahlsttom, Review of research: How leadership influences student learning. 2004. Wallace Foundation, available at: Google Scohlar.

[36] Education, Audiovisual and Culture Executive Agency "EACEA", Overview of the higher education system: Jordan. 2017. Retrieved from https://eacea.ec.europa.eu/sites/eaceasite/files/countryfiches_jordan_2017.pdf, available at: Google Scholar. 